\title{
Anthropocene: Anthropocene: does the New Geological Age push towards a Metamorphosis of the World
}

\author{
López Ortega, Jordi ${ }^{1, *}$
}

1 Universidad de Barcelona; Universidad Politécnica de Catalunya, jordi.lopez.ortega@upc.edu

* Correspondence: jordiortega@hotmail.com; Tel. 34.936.891.900

\begin{abstract}
The Anthropocene has created a new cartography. Various disciplines and discourses overlap each other. Two fields of knowledge: geology and anthropology are unified in one single concept. The Axial Age separated everyday practices from an unbiased and objective view of the world. Romanticism, in the nineteenth century, challenged the separation between the natural sciences and the sciences of the spirit. Paul J. Crutzen and Eugene Stoermer had two distinct parts; a first establishes "a period of time" the second an "epistemic tool". This paper is intended to illustrate the epistemological dimension of the Anthropocene. The Anthropocene defines the present geological epoch as dominated by humans. Eduard Suess, Antonio Stopani, Teilhard de Chardin, Vladimir Vernadsky etc., a century ago, anticipated the concept of Anthropocene. "Noösphere" is a term from the "world of thought". The hypothesis of an earth as a living organism, which is inspired by J.W. Goethe's "Naturwissenschaft", allows two disciplines to be integrated into one term: geology and anthropology. We have atmospheric phenomena that are incompressible without presupposing life. The Anthropocene modifies the foundations of our vision of the world. In the Gaia Hypothesis we find the same roots as in the Anthropocene concept: Goethe, Vernadky, etc. The concepts of symbiogenesis, homeostasis, etc., allow us to formulate new questions. This paper analyzes the reconfiguration of relations between the earth and all its inhabitants. it is, for the social sciences, a challenge: a metamorphosis of our vision of the world is taking place.
\end{abstract}

Keywords: Anthropocene, Noosphere, Biosphere, Morphology, Metamorphosis, Geophysiology 1. Introduction

The term Anthropocene was introduced in 2000 by Paul J. Crutzen (1933-2021). It is no coincidence that the term was introduced by an atmospheric chemist who won the Nobel Prize in 1995 with research into the chemical composition of the atmosphere. At a conference in Cuernavaca (Mexico) he heard "we are in the age of the Holocene", and exclaimed: "No! We are no longer in the Holocene, but in the Anthropocene!" (Arias-Maldonado, 2018).

To understand these changes, which social theory leaves unexplained, a break with the dominant metaphysics of social reproduction is essential. For this reason, the Anthropocene, exposed by Paul J. Crutzen and Eugene Stoermer (1934-2012), makes a distinction between two parts: establishes a "a period of time" and an "epistemic tool" (Arias-Maldonado, 2015: 126). We have the description of the problem as "something given" and, therefore, as a "problem to be solved"; but, remaining unnoticed to us, we can experience a metamorphosis of "being in the world". "The metamorphosis of the world" by Ulrich Beck (1944-2015) expresses this idea: climate change becomes the agent of the metamorphosis of the world: it focuses on the secondary consequences of chaotic anthropogenic environmental change from which a new world emerges: "how climate change is transforming our concept of the world" (Beck, 2016).

The reflections on the Anthropocene, in which it is affirmed that the human being has become a geological force, are dominated by the natural sciences (chemistry, physics, geology, etc.). This paper displaces the study from the natural sciences to the social sciences (anthropology, sociology, philosophy). Hannah Arendt (1906-1975) suggested that humans "being-in-the-world" had been disrupted in the modern age (Arendt, 1957). Martin 
Heidegger (1988-1976) points out that man loses his roots; he uses the term "unheimlich" (the root "heilmlich" names the foundation where man takes root). He expresses a correlation and an enigmatic game between "demand for the establishment of the foundation" and "withdrawal from the native soil" (Heidegger, 1997: 60).

He justifies the emphasis on the fact that the Anthropocene, used by different disciplines, leads to a "transdisciplinary and holistic" approach (Hamilton, 2016). It is not as simple as combining "empirical certainties" with "normative certainties" (Beck, 2016). The metamorphosis of the world -in the Anthropocene- has centered on the concept of "world"; while what is failing are the institutions. Hannah Arendt suggested, in the previous analysis, that thinking about the changing character of politics, science, freedom and thought is a real challenge for the humanities and social sciences (Palsson, et. al., 2013.8).

This paper will be divided into four parts: (2) show that atmospheric stability cannot be explained apart from life; the earth possesses, following Lovelock, a homeostatic capacity; (3) the hypothesis of a living cosmos and its relationship with humanity (so that it "dwells" in it); (4) philosophical anthropology, biological anthropology, and cosmological anthropology in relation to the Anthropocene; (5) utopias and dystopias in the Anthropocene.

\section{Anthropocene: geological era changes and epistemological change}

Eugene F. Stoermer (1934-2012) in the eighties used the term Anthropocene. He studied ecological changes in the great lakes resulting from human activity (Stoermer, 1984). The term Anthropocene is popularized from the year 2000 onwards; after the aforementioned conference in Cuernavaca in which Paul J. Crutzen proclaims a change of era. Together with Eugene F. Stoermer they publish an article in which they consider that the homo sapiens is no longer just a historical actor, it is a geological actor.

The term Anthropocene is not accepted by the community of geologists. For their acceptance they created "The Anthropocene Working Group" (AWG). The group seeks "evidence" of man's transformation of the biosphere and atmosphere. The magazine Nature (Jones, 2011) claimed recognition of the Anthropocene by "The International Commission on Stratigraphy (ICS)". The Anthropocene highlights two aspects: chaotic anthropogenic environmental change (which, on the one hand, undermines our response capacity and, on the other, allows us to proclaim human dominance and control) and a social, political and normative change for sustainability (the ability of states to govern has been significantly reduced, especially in the environmental context). These are urgent problems that cannot always find an answer within the dominant political institutions and scientific disciplines (Palsson, et. al., 2013: 9). Let's examine it in parts: (developed in 2.1) a new geological epoch and (developed in 2.2) the new scientific paradigm or epistemological change.

\subsection{A new geological era}

Paul J. Crutzen and Eugene Stoermer (2000: 17-18) first describe something very specific: how human activity alters the nitrogen cycle: "the earth's surface has been transformed by human action; more synthetic nitrogen (applied as fertilizer in agriculture) is now fixed synthetically and applied as fertilizers in agriculture than fixed naturally in all terrestrial ecosystems".

It has been pointed out that with the emergence of agriculture, man begins to alter the biosphere. The capacity for alteration of the gatherer and hunter societies was insignificant. Cities, with their increasing population, intensify agricultural production. It is 
not an evolutionary path: there is an abrupt, qualitative change with the "green revolution".

The challenges of agriculture focus on the use of inorganic nitrogen fertilizers and the development of agrochemicals that interferes with the nitrogen, carbon and phosphorus cycles (developed 2.1.1.). The IAASTD report (2009): "Agricultures at a Crossroad" is relevant and supported by six UN agendas and representatives of governments and civil society; it is unequivocal: the current model of food production is unsustainable. Agrochemicals are based on standardized monocultures (developed in 2.1.2). Agroecology makes an early critique of the "Green Revolution" that differentiates organic from inorganic nitrogen (developed in 2.1.3). What promised to end hunger on the planet has not only been a huge failure, which shakes the conventional discourses of science, but also generates new problems that require new paradigms (developed in 2.2).

\subsubsection{Challenge in agriculture}

Agriculture is presented as a human activity that impoverishes the fertility of the soil. We consider that all plant activity "depletes" the nutrients in the soil. We have had agriculture for more than 40,000 years, plant life for hundreds of thousands of years. We have created a big problem in the 20th century by altering the "cycle of life" and the cooperation between "the Five-Kingdoms" (Margulis, 1974). Today we have 821 million people suffering from hunger, another 2.2 billion suffer from malnutrition, mainly diabetes, obesity, vitamin and trace element deficiencies.

Between 1961 and 2019, "the use of nitrogen fertilizers" has increased by $800 \%$ (IPPC, 2019: 439). Annually, 128 million tons of nitrogen from the atmosphere (FAO data from 2008) are transformed into synthetic fertilizers to produce food. To produce this inorganic nitrogen, $5 \%$ of the yearly total of natural gas is spent (EU Agricultural, 2019). The nutritional problem, the energy problem, the climate problem and the problem of scarcity of materials for the agricultural model are consequences also of the nitrogen situation and need to be added. One calorie of food requires 10 calories of fossil energy, not counting machinery, transportation, etc. (Valero, 2019). A century ago, the relationship was the inverse: 10 food calories for one energy calorie. Another problem: this nitrogen pollutes the atmosphere, the rivers and 15.2 million tons of nitrogen have already ended up in the oceans (Rockström, et al, 2009). It causes hypoxia and aggravates eutrophication: excess nitrogen, phosphorus and organic matter leads to a loss of oxygen (Duarte, Pardo, et al., 2009: 95).

The causes of the problem are distributed thus: human activity, agricultural activity, economic activity, demography. There is no shortage of those, who faced with this, defend an ecological "apartheid". This paper examines agriculture based on standardized monocultures and genetic homogeneity (Weizsäcker, Wijkman, 2018). This paradigm was harshly criticized by IAASTD (2009). The notion of "carrying capacity" by Paul Ehrlich (1932-), despite its shortcomings, allows quantifying the anthropogenic impact on the environment. The environmental services provided by pollinators or microorganisms that make the land fertile have been systematically ignored.

In the last century, the use of synthetic nitrogen fertilizers has interfered with the organic nitrogen cycle (Mulvaney, Khan, Ellsworth, 2009). 1.310 million people are trapped in degraded agricultural land; it is estimated that 75,000 tons of fertile soil are lost annually. "It is a" global pandemic "of chemical pollution, acidity of the soil (and oceans), a microbial loss of the soil" (OECD / FAO, 2020). Nitrosamine, which is transformed in mineral nitrogen, is a carcinogenic compound. Modern agriculture methods add nitrogen and mineral phosphorus to the soil, they interfere in the oxygen and 
carbon cycle, they reduce the microbiological capacity with effects on the nutritive capacity and an increase in parasites.

The answer is polarized between those who see the solution in spraying the land with synthetic nitrogen (2.1.2) and those who bet on stimulating, with agroecology, the organic nitrogen cycle (2.1.3). We cannot ignore that phosphorus mines suffer a progressive depletion that leads to the collapse of the current global agricultural model (Valero, 2019: 131).

\subsubsection{Agrochemical}

Justus von Liebig (1803-1873) wrote "Die organische Chemie" (1840). He is the father of agrochemicals. The story begins when Alexander von Humboldt (1769-1859) takes samples of Peruvian guano to Europe to be analyzed (Meinhardt, 2019). It has a high proportion of nitrogen and phosphorus. In 1840 this resource began to be exploited with large imports for European agriculture. According to calculations, the mountains of guano could be exhausted in 50 years. Justus von Liebig advocated the "scientific" method for agriculture with the help of science and technology: the replacement ( $E r-$ satzes) of guano by an alternative in synthetic chemistry (Ceroni Galloso, 2012).

Justus von Liebig criticizes British agriculture for its "crop alignment". He considers that they are based on an "irrational method" (Foster, Clark, 2018). For Justus von Liebig, every plant, without exception, depletes the soil. Karl Marx (1818-1883) in Das Kapital saw in Justus von Liebig's theses a criticism of capitalist agriculture for squandering the "forces of the soil" (die Bodenkraft verschleutert). Karl Marx equates it to his criticism of the de-lapping of "labor power" (Marx, 1985: 821).

Justus von Liebig has sown discord between agrocology and ecosocialism (Foster, 2000). We have Darwinian social ecologists who predict a life-boat-ethics. Leopold Pfaudler (1839-1920) considers that if an element is lacking in one territory that is abundant in another, it can be taken from it. Justus von Liebig proposes a minimal exchange. It is about changing cultural contexts.

The exponential use of inorganic nitrogen in agriculture has increased over the last century. Chemist Fritz Haber (1868-1934) discovered how to narrow the synthetic nitrogen cycle to create fertilizers that could be added directly to the soil (Duarte, Pardo, 2009: 53). The German chemical industry, after the First World War, had a surplus of nitrogen that had been used to make explosives. Following Justus von Liebig's theory, it was used in agriculture. In 1918, Fritz Haber won the Nobel Prize in Chemistry. It was a controversial decision; the committee recognized that gaseous chlorine killed and maimed hundreds of thousands of soldiers (against the declaration of the 1907 Hague Convention). However, the Nobel tribunal considered chemicals to be an achievement in intensifying food production. The impact on health, through the food chain, led to a ban on organochlorines.

\subsubsection{Criticism from agroecology}

The chemist and naturalist Ragnar Berg (1873-1956) (1930), in the 1920s, considered that foods produced with synthetic fertilizers are organoleptically inferior to those produced with organic fertilizers. What is offered to us as fresh and healthy food has been harvested with the postulates of Justus von Liebig and, therefore, they are negative foods for health (Piulats, 2017: 222-223). For Rudolf Steiner (1961-1925) (2010: 135) they are "mere stomach fillers" (bloßen Magenausfüllungen) without "nourishing force" (Nährkraft). These are not very precise concepts. It shows the concern of farmers a century ago about the abrupt turn in agriculture and that today is expressed by the term Anthropocene. 
Farmers concerned about the development and consequences of agrochemicals asked Rudolf Steiner for a series of lectures in 1924. At these lectures, Steiner lamented the farmer's indifference for how nitrogen is prepared: where does it come from, if it is nitrogen from the air (dead) or organic nitrogen (Steiner, 2010: 16). There is a symbiosis between plants and animals; we breathe in nitrogen from the air that we excrete in the form of ammonia. What is toxic for us is nutrition to plants. One solution would be to improve the design of plants so that they ingest nitrogen from the air (Good, 2021). The agroecology approach considers that the organic fertilizers improve nutritional quality (Kirchfeld, Boyle, 1994: 148). We still do not understand this balance between animals, plants and mediating microorganisms (Prigogine, Stenger, 1984).

The fixation of fertilizers in the soil is no more than a century old. The use of synthetic nitrogen fractures the metabolism of life. This is expressed by the Anthropocene. The massive introduction of synthetic nitrogen is altering the cycle of life (nitrogen, oxygen and carbon). We see the disappearance of pollinators, it is more difficult for us to see the disappearance of fertility: the life of the soil (Weizsäcker, Wijkman, 2019). The biological community interacts in a biotic and abiotic way in the soil; without these microorganisms we cannot feed ourselves (Lehman, et al, 2015). Soil fertility is the most important intergenerational resource on which our survival as a species depends and it turns out to be the most underestimated resource (Weizsäcker, Wijkman, 2019). It is up to us to develop agriculture that improves soil fertility in the long term.

\subsection{The new scientific paradigm (new epistemological paradigm)}

Paul Crutzen and Eugene Stoermer (2000) mention pioneers who anticipate the concept of the Anthropocene. They are long-silenced authors. Georg Perkins Marsch (1801-1882) states, in his work "Man and Nature" published in 1864, a link between human activity and nature; points out that human activities have a transformative power on the morphology of the earth's surface. Antonio Stoppani (1824-1891), priest, geologist and paleontologist, describes human activity as a "new telluric force which in power and universality may be compared to the greater forces of earth"; in 1873 he used "the Anthropozoic era".

\subsubsection{Noosphere and biosphere}

The Russian geologist Vladimir Ivanovich Vernadsky (1863-1945) who published in 1926 should be highlighted. The Biosphere (Vernadsky, 1998). This term biosphere is inspired by Johann Wolfgang Goethe (1749-1832), Jean-Baptiste Lamarck (1744-1829), Alexander Humboldt (1769-1859), etc.

More than by The Biosphere, V.I. Vernadsky is known by Noosphere. Aristotle (384 BC-322 BC) uses the term voũs or vóos ("mind"). V. I. Vernadsky realizes that the chemical composition of the Earth's crust presents alterations in composition that are not explained according to the laws of physics, nor chemistry. Living matter arises from the processes of transforming the sun's radiant energy into organic matter through photosynthesis. It is a unique mechanism compared to that of terrestrial bodies. The distinction between living matter and inert matter begins, although they include each other, and an intelligence is incorporated (noós). "The noosphere is the third in a succession of phases of development of the Earth, after the geosphere (inanimate matter) and the biosphere (biological life)". Geosphere (inanimate matter) and the Biosphere (biological life) (Müller, 2020:354). The crust is the region of the biosphere, its epidermis, where life sits; this makes it possible to affirm that no living organism has been engendered by inorganic matter. If life disappeared from the Earth's crust, so would the cosmic processes. 
The hundreds of minerals resulting from chemical processes that occur in life, without it, would disappear. Mineral elements would be grouped differently. In 1875 the Austrian geologist Eduard Suess (1831-1914) (1875:159), in "Die Entstehung der Alpen", establishes that the speed of the Earth's rotation is the same, 33,100 centimeters/second, with which the energy of the bacteria circulates. It is not about properties of organisms, but also reflects planetary and cosmic phenomena. Eduard Suess thus extends the boundaries of the descriptive natural sciences and creates theoretical systems that encompass the whole. The philosopher, Jesuit, paleontologist and professor at the Catholic University of Paris Pierre Teilhard de Chardin (1881-1955) had already developed, shortly before, the notion of "noosphere" taken by Vladimir Vernadsky.

The "Gaia Hypothesis" of James Lovelock (1919-2019) and Lynn Margulis (1938-2011) considers that physical and chemical conditions have been and are still being adapted to the needs of life itself. It is similar to what Vladimir Vernadsky maintains. Here we point out that oxygen and other biogenic gases (CO2, NH3, and H3S) involved in life are products of life itself (Piulats, 2018:110). A postulate in contradiction with the official paradigm of science.

\subsubsection{The composition of the atmosphere}

Atmospheric chemists discover that the Earth's atmosphere is not the result of geological processes, but of biological processes. The molecules involved: carbon, nitrogen, oxygen, hydrogen, none of them is inert. We also have phosphorus and sulfur. They are molecules necessary for life and product of life. The constant balance for billions of years of $78.089 \%$ nitrogen and $20.946 \%$ oxygen makes the atmosphere a mystery (Piulats, 2017: 67). The researchers found that in the Cretaceous there was 35\% more oxygen in the atmosphere. If the percentage of oxygen fell, nothing would burn, if it increased by $2 \%$ the fires would be devastating. The surprise for Andrew G. Thomas was not to discover that in the Cretaceous there was more nitrogen, it was that the balance was maintained (Lovelock, 2006).

The Gaia hypothesis of self-regulation is more plausible. Vladimir Vernadsky (1998) launches from a hypothesis of the biosphere as a mechanism at the same time terrestrial and cosmic; the sun transmutes the face of the earth. Living matter transforms the radiant energy of the sun into chemical energy, therefore, living matter creates the biosphere. Those unstable compounds become stable equilibrium modalities. Therefore, if we extract nitrogen from the air of a room in which there is a person, we would find an immediate return to equilibrium. (Steiner, 2010: 71).

It is surprising how little or no interest in life has influenced the study of geology. When life is omnipresent in the biosphere and its balances depend on life, as Lynn Margulis (1986: 108) points out: in terms of information and order. Nature is a source of negative entropy (Lenton, et. Al, 2020). The Anthropocene brings us closer to understanding the world as an integrated functional whole, as a global phenomenon (Bertrand, 2014).

J.W. Goethe, when studying the atmosphere, realizes that mechanistic thinking cannot explain barometric oscillations: the atmosphere compresses (the pressure increases) and expands (the pressure decreases). This gives rise to air currents that regulate the temperature (increasing or decreasing the amount of humidity). In this ebb and flow he rules out that "extraterrestrial force" acts. His hypothesis is that of a living Earth. He likens it "to the inspiration and exhalation of an organism" (mit dem Ein- und Ausatmen eines Organismus) (Steiner, 1990: 201). 
These ideas from J.W. Goethe have inspired important scientists of the twentieth century. V. Vernadsky (1998) does not understand the insurmountable gulf between living matter and inert matter. When they influence each other. We have the feedback loop theory of Ludwig Bertalanffy (1901-1972), the homeostasis of Walter Cannon (18711945), the procedural philosophy of Alfred North Whitehead (1861-1947), the asserted systems of Ilya Prigogine (1917-2003), the complexity of the life of Manfred Eigen (19272019), the cybernetics of Heinz Foerster (1911-2002) and the autopoietic theory of Humberto Maturana (1928-), until the Anthropocene of Paul Crutzen and the geophysiology of James Lovelock (2006).

\subsubsection{Symbiogenesis between animals and plants}

Humans (and other animals) inhale oxygen and nitrogen and exhale carbon dioxide (CO2), but excrete nitrogen as urea. It is these residual products (metabolic waste) that make plant life possible (Lovelock, 2006). The Darwinian theory of evolution, if true, would have endowed us with a more efficient physiology. If uric acid were exhaled, as we do with CO2 in the breath, we would avoid a high consumption of water (4 liters / $100 \mathrm{~g}$ of urea) and energy expenditure (379 kilojoules / $100 \mathrm{~g}$ of urea). Plants are not efficiently designed either: they need organic nitrogen (Good, 2012).

James Lovelock suggests considering the Earth as a physiological system; For this reason, he suggests that the techniques to improve the land (with geoengineering) would address diseases in the same way medicine did in the 19th century (Lovelock, 2008). Bill Gates (1955-) (2021) defends this type of solutions in emergency situations, like the one we are in now. Contextual frames are important. From worrying about the $\mathrm{CO} 2$ that we emit when we breathe, we turn to worrying about a supposed depletion of oxygen (by joining carbon). When breathing oxygen and nitrogen, the latter carries oxygen to meet carbon and we expel it as carbon dioxide (Steiner, 2010: 69). The ability to remove carbon prevents us from having the rigidity of the plant (Steiner, 2010: 65). It is the climatic regulation in a geophysiological model (Lovelock, 1994); however, we do not understand the extent of coupling and feedback between plant growth, global temperature and enhanced atmospheric concentrations of greenhouse gases.

Darwinian evolution is incompatible with the Gaia hypothesis (Lovelock, 2006). A selfish gene would have favored a mutant gene that excretes urea to save water and energy. The response of the biochemist, of a teleological nature, is that we excrete urea instead of nitrogen because it is toxic. James Lovelock's reaction would be, "explain it to bacteria". A symbiogenesis with bacteria, which breaks down nitrogen, would have been as good or better a solution than metabolizing urea. If we were more efficient and exhaled inorganic nitrogen, plants would have nothing to nourish themselves or to feed us (Lovelock, 2006).

The diversity of living organisms is the result of the relationship of very few elements (N, O, C, H, S, P). Its composition and shape are not determined by chance, because of its chemical structure, it obeys "an order and structure" (Margulis, Sagan, 1986: 51). The morphological composition of plants studied by J. W. Goethe is not dominated by the "physical fields" but by projective geometry (following the laws of the organic world). Here we go back to Hans Driesch who discovered a pattern of self-organization. We have more controversial theories. From complex catalytic networks to feedback loops. Rupert Scheldrake (1942-) attributes the development and maintenance of life to "morphogenetic" or "morphic resonance" fields (Capra, 1986).

The geometry of minerals is centrifugal: it fills the space subjected to gravity. We find polarity: centrifugal and centripetal, in living organisms. Breathing reminds us: breathe in and breathe out. It is not very concrete to speak of "formative forces". The 
question of the origin of life may be poorly considered. The Nobel laureate Francis Crick (1916-2004) uses the term "panspermia": the hypothesis that the origin of life is in Extremophilic organisms (Peinado Loca, 2019). NASA found RNA components in meteorites (Furukawa, Chikaraisch, 2019). Oxygen, discovered by James Lovelock and Lynn Margulis (1974), is a molecule involved in life produced by life itself. It is not in an inert state.

\section{Towards a physiology of geology: a living cosmos}

Several concepts point to a living cosmos: the Gaia hypothesis, symbiogenesis, homeostasis, etc. They face the mechanistic model and Darwinian evolutionary theory that are based on competition between species. Life did not conquer the planet with combat, Lynn Margulis and Doris Sagan (1986: 15) point out, but with alliances and cooperation. Epigenetics knows that there is an interaction between the inside and the outside. J.W. Goethe (1982.71) discovers that there are not the exterior conditions; but the interior, the form, that are the determining factor.

The morphology of animals and plants is more than just collaboration. Digestion is done at body temperature; Human technology, on the other hand, to break the nitrogen molecule requires a lightning storm voltage (Naredo, Valero, 1999: 197). Science verifies physiological processes are more efficient than human technology.

\subsection{Mechanical vision and organic vision}

By verifying chemical reactions, we become blind to the collaboration that occurs between the five kingdoms of nature (Margulis, 1974). Natural processes are syntropic (negative entropy). Our arrogant chemical understanding makes them entropical. Ilya Prigogine (1917-2003) questioned the mechanistic dogma and the second law of thermodynamics. Although Chaos Theory or dissipative structures are praised (Naredo, Valero, 1999: 163), ecological-economy is reluctant to go against the second law of thermodynamics as it would weaken the awareness of environmental limits.

\subsubsection{Symbiosis between the animal and plant world}

The man would be an inverted plant; in the plant the cosmic acts in the root, the terrestrial in the flower (Steiner, 2010: 53). The hypothesis of a "plant intelligence" developed by Stefano Mancuso (1965-) (2019) continues the work of some 19th century physiologists that had not been worked on since and have not been free of controversy. He believes that plant networks act in much the same way as our neural networks. A provocative work is Elementer des Psychophysik (1860) by Gustav T. Fechner (1801-1887) depicting a living cosmos. We find in the last paragraphs of On the Movements and Habits of Climbing Plants (1875), by Charles Darwin, that analogy between the brain and roots of plants and he proposes a "plant neurobiology". Another plant physiologist, Anthony J. Trewavas (1949-), of the University of Edinburgh questions the difference between biology, botany and anthropology.

J.W. Goethe (1982: 24) considers nature to be a sensible person (eine verständige Person). James Lovelock, on the other hand, takes it as something metaphorical, an "aide pensée" (Lovelock, 2006:20). He rejects that the symbiogenesis or homeostasis of the planet has a purpose (Lovelock, 1991: 11). Established science has been more opposed to the Gaia hypothesis than other theories based on self-organization in a dogmatic way; it dismisses the Gaia hypothesis as teleological (Lovelock, 1991: 43). 
In autumn, the leaves provide energy and nutrients for fungi and microorganisms that nourish the soil. There are interactions between the 5 kingdoms of nature that have smart grids in which some learn from others inspired to improve resilience (Pauli, 2021). The intelligence of biology is very efficient; on the other hand, human technology has a high thermodynamic cost (Naredo, Valero, 1999: 189). Nature, said J.W. Goethe (1982: 24), "does a lot with little, while others do little with a lot".

\subsubsection{The Place of Man in the Cosmos}

It is paradoxical to characterize an era as Anthropocene and, in turn, support environmental criticism of anthropocentrism (Arias-Maldonado, 2015, 2018). "Metaphysics" is supplanted by "anthropology" (Heidegger, 1997: 129). The next step is "the struggle for dominion over the land" (der Kampf um die Erdherrschaft) (Heidegger, 1997: 261). How is man different from chimpanzees? Studies reveal that they share the ability to direct symbolic signals to their peers. But man does something that chimpanzees cannot do, points out Michael Tomassello (1950-) (2002: 23-26): they establish communication through intersubjective semantic processes that allow man to enter into dynamics of cognitive innovation.

There are no physiological or anatomical differences between man and higher animals except for the intermaxillary bone discovered by J.W. Goethe (Steiner, 1987: 34, 45). Pierre Teilhard de Chardin discovered another distinctive feature: each species has its habitat, man lives wherever (Ortega y Gasset, 2014: 209). What makes man an ontological centaur points out José Ortega y Gasset (1883-1955) (2014: 209): “the Earth is uninhabitable for man -inbewohnbar" (2014: 209). Man is a soul in a body; but he is neither the one nor the other; it is a drama: a struggle to become what I have to be (Ortega y Gasset, 2014: 87).

Unlike animals, who exhaust their "formative forces" by specializing, man retains them and uses them in cultural capacities (Piulats, 2018: 166). This cognitive innovation has made possible an accelerated technological disruption; Not only have we altered the geological system causing an ecological collapse, it also gives us the power to reshape our inner world, endangering our very essence as human beings (Harari, 2018). The Anthropocene becomes a new talisman of human consciousness.

The emancipation of man in the Anthropocene would endanger the habitability of the earth: an apocalypse. Man is more than just an animal endowed with technical talent. The key lays, for Manuel Arias-Maldonado (2021) in planetary subjectivities. Dana Meadows points out that the "psychic void" is a force towards an insatiable appetite for material growth rather than seeking further inner development (Weizsäcker, Wijkman, 2018). There are those who accuse Christianity of evil and, as a result of it, science and humanism are also doomed.

Two centuries ago, James Lovelock (2006) points out, we were in time to establish "sustainable development" guidelines. It leads us to a question: at what point, for example, did the inhabitants of Easter Island miss the time to act? Harald Welzer (1958-) (2008: 211) considers that it is a problem of a badly posed question. The scientific answer tells us when the forest could no longer regenerate itself. Today, in the face of the climate emergency, geoengineering is proposed instead of geophysiology (Lovelock, 2008). Harald Welzer poses a sociological question: "social catastrophe" occurs before the last tree is cut down. The catastrophe begins with a decision being made in the wrong 
direction. What makes us change cultural frames of reference are not threats, but opportunities. Felipe III (1578-1621), King of Spain, died because of not breaking protocol: he remained next to the brazier waiting the person in charge of it. After high fevers, an erysipera occurred that caused his death. But he had alternative options (Welzer, 2008: 82). Societies that hold fast to the protocols or rules become 'extinction societies' (Verlebensmeinschaft) while the ones that are able to learn become 'suirviving societ ies' (Überlebensmeinschaft). (Welzer, 2008:274).

\subsection{Epistemological promiscuity between anthropology and geology}

There is no doubt that the Anthropocene has strong empirical data on human influence behind it. This paper, however, focuses on the relationship discovered by Norbert Elias (1897-1990) between sociogenesis and psychogenesis: the empirical data of the outer world and the interpretive frameworks of the inner world (Welzer, 2013). From the relationship between "communication" and "world" arises the concept of "Weltkommunikation". A concept by Karl Japers (1883-1968) that is central to the sociological theories of Niklas Luhmann (1927-1998), Jürgen Habermas (1927-) and Ulrich Beck (1944-2015).

We cannot distinguish between metamorphosis of the world and communication of metamorphosis (Ulrich Beck, 2016). This means that nature is not understood "from outside" of society. The destruction of nature, beyond its anthropogenic or natural origin, is not a "simple" destruction of nature; it is an agent of the metamorphosis of the world or of social and political dynamics. The Anthropocene, beyond proclaiming the interdisciplinarity between geology and anthropology, supposes a provocative "epistemological promiscuity" (2018: 4).

Aristotle would say that interdisciplinarity can be said in many ways. Merging natural sciences and spiritual sciences can go beyond the fields and competences of the different disciplines. there is no single point of collision. Cybernetics is at the height of complex systems; but a degree of cognitive perfection can erase the difference between machine and man (Gadamer, 1993). Jürgen Habermas (2001) shows the conflicts between the autonomy of scientific research and the normative limits; certain gene therapies can alter our understanding as a species. Modern science has created "The Castle" by Franz Kafra (1883-1923) emancipated from its inhabitants: it is where the ladder of abstractions of Niklas Luhmann's theory leads. We are before a self-sufficient and autopoietic castle, without subject and suprasubjective: a "return of metaphysics" after "the end of metaphysics" (Beck, 1988). The ecological discourse is structured on the basis of the scientific discourse and develops a political action against established science (Arias-Maldonado, 2018: 17). We will analyze the need to unite anthropology and geology and overcome the division of disciplines (3.2.1); its consequences in the understanding of life and the cosmos (3.2.2); the consequences of the Anthropocene for social theory (3.2.3).

\subsubsection{Interdisciplinarity between anthropology and geology}

The Anthropocene is an invitation to interdisciplinarity. Geology is "descriptive"; but it uses, with some lightness, an anthropological terminology: normative. The natural sciences are competent to treat physical problems: they reach extreme acuity; but they tend to dimension social problems with enormous political and sociological naivety. Sociologists, philosophers, anthropologists find it irritating that together with a sharp scientific analysis superficial normative argument are found (Welzer, 2008: 46). The descriptive "objectivity" of a problem does not produce a metamorphosis of political action and a change in daily behavior (Beck, 2015). It is an old debate. Remember the fallacy 
many sociologists fell into when from "revolutionary objective conditions" derived a "revolutionary subjective consciousness".

Edward O. Wilson (1929-) unifies, in his own way, the natural sciences and the social sciences. He proposes an evolutionary ethic based on biology and temporarily marginalizes philosophers (Wilson, 2016). Climate change turned into a supermarket of apocalyptic hypotheses (Beck, 2016), does not provoke an institutional metamorphosis, nor does it generate a technocratic consensus imposed from above. These are mergers between disciplines that are on the antipodes of uniting society and the biosphere under the concept of "coevolution" (Duarte, Pardo, et. al., 2006:128). For James Lovelock (2006) science tries to be global; more than a series of unconnected of disciplines.

The Anthropocene links a series of scientific theories from which to contemplate the evolution of geology and living beings, not as separate sciences, but as a holistic whole (Piulats, 2018: 111). The emergence of global ecological problems attracted renewed attention, at the end of the 20th century, towards interdisciplinarity to study the interdependencies of the parts with the whole. A good answer was "environmental impact studies". Accademia is debating particularism under the acronym "STEM" (science, technology, engineering and mathematics) and universalism of the "four Cs" (creativity, critical thinking, communication and collaboration) (Weizsäcker, Wijkman, 2019).

Academia differs from the higher training schools. It does not teach trades. In its beginnings it was divided into four faculties: medicine, theology, law and philosophy. The University of Salerno, medicine; Bologna, law; Paris, theology and philosophy. They do not transmit "specialized" knowledge, the knowledge they give to their students is universal. Nor do they handle in the instruction geared towards the occupation of public positions as does the oriental academia ("mandarinate"). Nowadays, science with the sole criterion of quality in measurability is losing its reputation.

The 12th century has something explosive (Bachmann, Fidora, 2008). The conflict between theological power and political power weakens them both. Man frees himself from the suffocating pressure of the ecclesiastical authorities and the absolutist state. It gives rise to freedom of thought and autonomy of conscience (Weizsäcker, Wijkman, 2019). A public sphere of free citizens was created Likewise the Anthropocene has something explosive: it rejects established scientific disciplines in favor of a new totality. For Ulrich Beck (2016) this is visible in the reproduction of the social and political order.

"The new paradigm of Earth System science is erroneously understood as no more than a variation or development of established ecological sciences" exposes Clive Hamilton (2017). This confusion is due to the radical novelty of this new paradigm (Arias-Maldonado: 2018: 5). Some approaches are based on the scientific method. For this reason, it is not easy for an "emerging body" to develop that merges the different disciplines (Arias-Maldonado, 2015: 125). Debates at the beginning of the 21st century can learn from debates that took place at the beginning of the 20th century: it was clear that knowledge was fragmented and an integration of this fragmented knowledge into an "interconnected totality" was urgent (Arias-Maldonado, 2018: 11). This integration has several dimensions: (i) there is no knowledge without interest, as Edmund Husserl (1859-1936) pointed out; (ii) there is no knowledge without interpretive coordinates or historical-cultural parameters, points out Harald Welzer (1958-); (iii) there is no global catastrophe without communication or "Weltkommunikation": a concept that takes divergent paths in Jürgen Habermas, Niklas Luhmann and Ulrich Beck. 
J.W. Goethe does not understand, in sociological terms, the nature "from the outside" of society. Nature, at the end of the 20th century, is the "immobilized interior of the civilized world". But the ecological crisis does not represent a destroyed or threatened nature, since its socialization (Vergesellschaftung) transforms it into an essential element of the political, social and cultural dynamics (Beck, 2015). Adaptive policies are onesided. Charles Darwin (1809-1882) considers that biology is conditioned by the fluctuating external environment, finding nothing constant inside organisms. It happens that evolutionary theory develops only a part of the ideas of J.W. Goethe; it does not develop what external forces act on (Steiner, 2010: 18), there is an incomplete image of the interaction between the organism and nature. The "law of inheritance" by Ernst Haeckel (1834-1919), father of the term ecology, does find that interior archetype on which external forces act in such a way that it stimulates the deployment of internal creative forces (Steiner, 2010: 77). If we take climate change unilaterally, we will consider its origin unequivocally anthropogenic and with social consequences; but we are blind both to the "anthropological shock" and to its ability to modify our worldview of the world by triggering a metamorphosis (Beck, 2015).

Science, at the beginning of the 20th century, emancipated itself from "Euclidean geometry". Launched a revolution. It accepted that the act of measuring can alter the results of measurement: the inability to measure - accurately - two properties at the same time. The "complementarity principle" of Niels Bohr (1885-1962) and the "uncertainty principle" of Werner Heisenberg (1901-1976) rehabilitate the observer. José Ortega y Gasset (1938: 149) would say that in the cosmic spectacle there is no observer without a specific location. J.W. Goethe anticipates that scientific revolution. He influences Vernadsky, Suess, etc. Sociology does not understand nature "from outside" of society. Nature, at the end of the 20th century, is the "immobilized interior of the civilized world" (Beck, 2016). The ecological crisis does not represent a destroyed or threatened nature, since its socialization (Vergesellschaftung): becomes an essential element of the political, social and cultural dynamics (Beck, 2015).

Charles Darwin (1809-1882) considers that biology is conditioned by the fluctuating external environment. The nineteenth century novel ("expérimental roman") the man ceases to be the protagonist. The "medium" is the protagonist. Charles Darwin takes the landscape as the protagonist by not finding anything constant inside the organisms that adapt to the environment. His theory of evolution develops a part of the ideas of J.W. Goethe: he does not develop on what external forces act (Steiner, 2010: 18). It offers an incomplete picture of the interaction between the organism and nature. Ernst Haeckel's (1834-1919) "law of inheritance" finds that "inner archetype" on which external forces act: in such a way that it stimulates the deployment of "internal creative forces" (Steiner, 2010: 77). The primary effects of climate change address this in a unilateral way: the unequivocally anthropogenic origin. The social consequences show us the secondary effects: the "anthropological shock" has the capacity to modify our worldview of the world (Beck, 2015).

The same type of polarity can be found in J.W. Goethe and Immanuel Kant (17241804): Kant distinguishes the critique of pure reason (a mathematical physical model that offers an unfinished knowledge) and a practical reason (which is a decisive knowledge that cannot wait for an unattainable universality). Medicine is an art of healing, a practical, decisive knowledge (Gadamer, 1993). Medicine forms art (practical knowledge), that is, tékhné Iatriké. It does not mean that the knowledge is not applied in medical practice; there is a good collaboration between knowledge and practice. The doctor has the last word: the "clinical eye", the "therapeutic intuition", and so on. In medicine theory and practice go hand in hand. 
In J.W. Goethe's "Dichtung und Wahrheit" (Poetry and Truth), written between 1811 and 1830, the search goes beyond dualistic thinking: it establishes a rhythmic point. Kant established a third criticism: Urteilkraft (judgment). The philosopher Johann Gottlieb Fichte (1762-1814) has the brilliant idea of grounding the world on the circular (self-referential) movement of consciousness; but he creates enormous confusion: "The Ego postulates itself". G.W.F Hegel (1770-1831) recognizes the impasse: a circle without beginning and without end. This tremendous confusion between consciousness and world, system and society, etc., fascinates sociologists (Beck, 2016). It is one of the causes of the crisis of civilization, Edmund Husserl (1935) points out: he proposes a rebirth, in Europe, in the face of the danger of "fatigue", of a new spirituality like a Phoenix. Atmospheric chemists have found that the balance of gases in the atmosphere is not explicable without some "intentionality". Edmund Husserl had proposed to recover Aristotle's ontology that considers that nature has a teleological purpose (Habermas, 2012). Geology, as a "gigantic living organism" (although it does not coincide with what we understand by intelligent life), would be endowed with a certain "intentionality". Quantum physics has paved the way to stop seeing the world as something "outside of us". And yet, we continue to think that the world is something that existed before and will exist later (Lachman, 2017: 42).

\subsubsection{From social classes to the anthropogenic class}

Sociology has detached itself from nineteenth-century visions to understand that nature does not exist "outside" of society. Sustainability policies, however, continue to invoke "the natural" as something "outside of us" (Arias-Maldonado, 2016). Social theory has been articulated in the conflict between "knowledge" and "intention" or between "work" and "interaction" (Habermas, 1968). Or, in Marxist terms, the conflict between the "productive forces" and the "relations of production." Today, more than "production relations", it would be more appropriate to speak of "defining relations" (Beck, 2016). The "social class" and the "anthropogenic class" can be interchangeable concepts, but they belong to different worlds (Beck, 2016).

The concepts of "class society" and "social classes" designed to explain the distribution of goods are lame to explain the new social inequalities of the Anthropocene. Climate violence is written by climatologists, geologists, etc., as an increase in the acidity of the oceans, an increase in temperatures, a loss of biodiversity, etc.; the new perspective of inequality in the Anthropocene does not exclude the "observer": the focus is on the metamorphosis of politics and society. The Anthropocene, more than a new geological era, is a profound epistemological and normative horizon change that modifies our relationship as human beings with ourselves and with the rest of nature (Steffen et al., 2007: 614).

The social theory does not explain the distribution of evils, this is done by the risk theory. Evil, as a secondary consequence, causes an "anthropological shock" that transforms society, politics and culture. Well beyond the current supermarket of apocalyptic hypotheses that is climate change, we start to pay attention to the new norms, structures and beginnings (Beck, 2016). There is a hidden relationship between "climate catastrophe" and "emancipatory catastrophism". Climate change causes also an "anthropological shock" that initiates cultural, social and political transformations, an "emancipatory catastrophism" to the extent that it frees us from old structures and old norms.

The distribution of evils is superimposed on the distribution of goods. The theory of risk allows adding to the theory of social class that explains the distribution of goods 
how evils are distributed. But when these evils are metamorphosed into goods, due to their "secondary effects", the discourse of "climate justice" refers to former winners and losers. Many questions are poorly posed. The question is not who wins and who loses, but what social and political processes revolve around climate change, not as a physical process, but as an agent of the metamorphosis of society. All the old cartography of social theory is useless.

We see man as a geological force causing climate change. The secondary consequences of climate change are an even more transformative force in epistemology, society and politics. The sciences, including the social sciences, give little relevance to "side effects." We believe that the picture of the world provided by science is impartial, the result of an observation, measurement and description (observation, measurement, description). Science, however, does not have a "contemplative" attitude; but rather, it is "imperative" (Ortega y Gasset, 1938: 106). The rational spirit does not observe, it interrogates. We can interrogate by asking a scientific question: what to do about climate change? The answer is a description of climate change. We can ask an analytical and sociological question: how does climate change alter the social and political order and the interpretive coordinates and cultural frameworks? The answer will be the opposite of the first: how "public evils" are metamorphosed into "public goods" (Beck, 2016).

The Axial Age leaves the world divided. For Helmuth Plessner (1892-1985) (1981) human beings are eccentrical: we are a "body" (Körper) endowed with "life" (Lieb). In the words of Ulrich Beck (1944-2015) (2016) we have "the macro level of the world" and "the micro level of everyday life". The Anthropocene would merge these two levels. The sociology that deals with the evolution of society and geology that deals with the evolution of the earth, are now intertwined. Proposals, in the last decades, open the way for an Earth seen as a "gigantic living organism". It must be taken as a hypothesis, not as a scientific statement. The Darwinian vision guided by selfishness and competition is by a new image (Gaia) in favor of a cooperation between rocks, microorganisms, plants and other living beings.

\section{A physiology of geology: a cosmos as a living organism}

There are attempts to put into practice this integration of various scientific perspectives - hitherto separate - such as the Association for the Promotion of Science Research in Germany. Although we can go back to the beginning of the 20th century when Albert Einstein, Lise Meitner, Fritz Haber and Otto Hahn investigated at the Kaiser Wilhelm Institutes (Costanza, Graumlich, Steffen, 2007).

Microbiology developed the concept of symbiogenesis from studies of bacteria networks with self-regulation capacity (Aanen, Eggleton, 2017). Illustrious precursors such as. Gustav T. Fechner (1801-1887), professor at the University of Leipzig, physician, philosopher, physicist and naturalist, understand the cosmos as an animated whole in Ideen zur Schöpfungs- und Entwicklungsgeschichte der Organismen (1873). Gustav Fechner (2011) uses the term psychophysics to also consider that the stars have life. Heinrich Heine (1797-1856) (1969-1976:VI, I, 479) understands the philosophy of the spirit of G.W.F. Hegel (1770-1831) as a process in which "God becomes self-aware in man". It proposes this synthesis between flowers and nightingales to twin sensualism and spirituality, social justice and beauty, Jewish asceticism and hellenism that Hegel, Hölderlin and Schelling had dreamed of (Habermas, 2013). We will deal with the problem of evil (4.1), our role as repairers

of the cosmos (4.2) and the plausibility of geophysiology (4.3). 


\subsection{The loss of meaning of the world}

The separation between natural sciences and social sciences is a wall that prevents ecological catastrophe from becoming an agent of the metamorphosis of the world (Beck, 2016). The origin of this gap between the "world of life" and the "objectified world" is located at the moment when the axial reformers allowed to build the great coherent and transmissible systems of knowledge. It is one of the greatest cosmological revolutions. The whole, encompassing the "world of life" and the "objective world," is separated. The Babylonian astrologers, the Egyptian geometers and mathematicians, etc., unlike our astrophysicists, mathematicians, etc., had no less knowledge, the great systems of knowledge went hand in hand with everyday practices. In Aristotle, normative arguments still went hand in hand with empirical reflections (Habermas, 2006).

\subsubsection{The Metamorphosis of our Concept of the World}

Ulrich Beck (2015) focuses the analysis of the Axial Age (Achsenzeit) in disputes between the "moral divine order" and the "social and political (earthly) order"; the spiritual elites intended to assert their yardstick of the transcendental order in the temporal order. And since then the "homo sapiens" and the "homo ritual" took different paths.

In the 12th century the explosive conflict between the discourse of revelation and the discourse of reason erupts. It is a conflict between two spiritual currents. Opposing concepts are sharpened: science and belief. The arabist reception of Aristotle had excluded the possibility of discovering in nature a "divine manuscript". Christian scholasticism finds that manuscript in nature, through Aristotelian ontology (Lutz-Bachmann, Fidora, 2008). Scholastic nominalism will pave the way for an empirical and impartial contemplation of nature that leads Rene Descartes (1596-1650) to separate the "res-cogita" and the "res-extensa": the natural sciences (the experienced) versus cosmology or sacred history (the lived). Friedrich Nietzsche (1844-1900) warns, in a fragment entitled "Hinfall der kosmologischen Werten" (1887-1888), of a "devaluation of the supreme values" (der Entwertung der obersten Werte). In it designates "den Hinfall der kosmologischen Werte" (the expiration of cosmological values) as noted by Martin Heidegger (1961:55-58).

We have contextualized the debate about the meaning of evil (Steiner, 1981). Jürgen Habermas (2019:361,546) draws the consequences of the dispute in the early centuries between the Neoplatonism of Celsus (2th century) and Plotinus (205-270) versus the early Christians, Tertullian (160-220) and Augustine of Hippo (354-430). It is more than just a theological or philosophical dispute. Jewish mysticism and Protestant mysticism, which have in Isaac Luria (1534-1572) and Jakob Böhme (1575-1624) two of their highest representatives, formulate a theogony and cosmogony in which God is exiled to the darkness of his own foundation without foundation: God becomes his other and nature extends into God (Habermas, 1963). Hermetics and agnostics agree that man had descended from the spiritual world. But, while for Christians, Hermetics and kabbalists it is a "leap", for agnostics a "fall". The body, for agnostics, is a prison from which the spirit has its only salvation in escaping.

\subsubsection{Manichaeism and metamorphosis}

Hermes Trismegisto, asked by Asclepius about why possess a body, replies that the body allows the spirit to take care of creation (Lachman, 2013). More than a geological time we fix an anthropological time. But it is important for geological evolution. We 
have the inner gaze of Buddha (the gospel of Luke), the look at the cosmos of Zoroaster (the gospel of Matthew). These two currents come together in Christianity to rejuvenate them (Habermas, 2019:361).

There are two approaches to the problem of evil (Steiner, 1981: 94; Steiner, 2014). Pelagianism refuses to admit that evil cannot be eliminated from the earth by human effort (Riechmann 2017:160). Manichaeism, on the other hand, does not suppress evil: darkness must be redeemed by itself. Man's task is to send that "spark" into darkness so that "evil" may be metamorphosed into "good". Jorge Luis Borges (1899-1986) in "The Rose of Paracelsus" puts in the mouth of Theophrastus Bombast von Hohenheim: "Do you think that divinity can create a place other than Paradise? Do you think the Fall is nothing more than ignoring that we are on Paradise?" All nature is at the service of man (an "anthropocentric" hypothesis); but, he adds: "no substance can be used without great art... the human being is to transform it" (Paracelsus, 1965:544). Celsus, famous for his attacks on Christianity, as well as neopagans and agnostics, believes that the world was created by a kind of idiot God; we are spiritual beings trapped in a physical and evil cosmos.

The response to the planetary ecological crisis, for John Gray (2015) in "The Soul of the Marionette", consists of returning to those older religions where the problem of evil did not exist; then we lived in a world that contained light and darkness, creative and destructive forces, good and evil. Evil, for John Gray, has its origin in Zoroastrianism, Manichaeism, Rosicrucians, Cathars, etc. He finds in the scientific revolution, even if he denies Christianity, a byproduct of magic, alchemy, etc. It does not leave out Issac Newton (1643-1727) who believed in numerology and sought hidden meanings in the Bible. Before Bodhisattva adopted Buddha's, body there was no guilt; man, if anything, was possessed by evil. Jesus, influenced by Zoroastrian ideas understands life as a war between light and darkness, between good and evil.

\subsubsection{Agnostics against Gnosis}

James Lovelock agrees with John Gray not only in his criticism of Christianity and humanism, but also in his faith in progress and in a human being who is too fragile to accept the truth. According to him, "sustainable development" is that faith to be eradicated and replaced by, the inevitable, "sustainable withdrawal" (Lovelock, 2006). A previous step to discussing anthropological and cosmological pessimism is to let geologists, biologists, oceanographers, etc., speak; and, in a second moment, points out Jorge Reichmann (2017:261), debating this pessimism from Giacomo Leopardi (1798-1837) or Arthur Schopenhauer (1788-1860), etc.

It is not in scientific terms that John Gray (2003) blames humanistic and Christian mental infrastructures to add that men are ill-conceived and ill-made creatures (Gray, 2015). He agrees with the sociologist Lewis Mumford (1895-1990) who contrasts the irrationality that runs through human history with the wisdom and rationality of the animal. In his work The Myth of the Machine (Mumford, 1971) he reveals, in human evolution, a chronic predisposition towards error, evil, exorbitant fantasies, etc.

John Gray, says Gary Lachman (2013); does not argue, it simply asserts and takes advantage of any mention of the human being to lower its fumes. Walter Benjamin's (1892-1940) $(1980,698)$ agrees in criticism of progress but in some points is very different from Gray's. "Über den Begriff der Geschichte", with the view that the SPD's "Gotha program" is a "secularized resurrection of Protestant labor morality"; from where fascism will later develop. Walter Benjamin in 1921 acquires the Angelus Novus of Paul 
Klee (1879-1940). Klee describes it as The Angel of History ("Der Engel der Geschichte") that is pushed, inexorably, into the future; but, at the same time, turns its back to it: it looks to the past where ruins accumulate. Look to the past, as the hurricane, which we call progress, pushes you into the future (Benjamin: 1980, 697). Walter Benjamin, unlike John Gray, retains the hope that man can rebuild unity in a whole after the "breaking of vessels" (shevirat-ha-kelin, in Hebrew). The prophets of the apocalypse and those who preach faith in technological progress look to the past. Optimists and pessimists retain a "larval worldview", that is, they are not aware of their imminent metamorphosis, like the caterpillar, into a butterfly. They cling to the cocoon (Beck, 2016). They do not experience the tremendous transformation of their referential horizon.

\subsection{Guardians of the cosmos: Buddha, Zoroaster and Christ}

Isaac Luria (1534-1572), the great 16th century Kabbalist from Safed, and Jakob Böhme, shortly after, consider that man has a task. The common point is the "doctrine of the fall" of Adan Kadmon (Habermas, 1964). In Hebrew the term "tikkún" is used, which translates as "repair" (Lachman, 2013). In the nineteenth century Soren Kierkegaard (1813-1855) considered that there was no such "fall", it was a "leap of faith". He recovers the idea that men are "cosmic repairers".

Against this mystical movement, the idea of human insignificance makes its way; man reduced to nullity and, at the same time, turned into a geological force that is killing the Earth. Man, as we will see, is part of two worlds: the kabbalists who know that Adam (גז) without the "Elf" means blood (Dam in Hebrew). Adam unites the blue sky and the red earth.

The idea of "tikkun" suggests that when God creates the world "out of nothing", something did not work out. As Isaac Luria points out, he creates man "of something" and woman of man. He transmits the spirit to that something. That is why for Isaac Luria and the Kabbalists man can, thanks to the "divine spark", stop the escalation of ecological destruction.

\subsubsection{East and West: Zoroaster and Buddha}

There are those who insist on seeing man as dust mops in the infinite universe, and gives him the condition of fallen angels whose only way out is "detachment", "asceticism", "meditation". A will not to know anything about the earthly. Man, on the other hand, houses within himself the eternal and infinite as suggested by the scientist, philosopher and mystic Emanuel Swedenborg (1688-1772). He anticipates an idea, previously stated, that the universe intends to harbor intelligent life. Jorge Luis Borges describes him in a story: he worked in the mines, studied anatomy, aeronautics, etc., but refused the chair of Astronomy at the University of Uppsala because it was too theoretical a dedication.

Pindar sums up man's heroic task: "to become what he is". Today we are not so sure of an unlikely "technocracy" as José Ortega y Gasset (1883-1955) (2014:95) continues; he considers that the technique cannot command, it is secondary, because the main thing of man is to make himself, to self-manufacture himself (2014:90). Today's man lacks imagination to know what he wants to be. Yuval Noah Harari, (2018) tells us that if we don't know what we want, it will most likely be easy for technology to shape our lives and decide for us. Life is not just about fighting matter; it is, fundamentally, a struggle with the soul. The body and soul are things, the man, says Ortega y Gasset (2014:87), is "a 
drama". He contrasts the "Bodhisattva project": the one who is "self-absorbed" within himself, and the "Gentleman's project": the one who "alters" himself in a struggle for life, exercising professions, etc. The Jesus of the line of Nathan, in the gospel of St. Luke and the Jesus of the line of Solomon (strains of David), in the gospel of St. Matthew come to unite and renew these two spiritual currents: the eastern technique of Buddha (563-483 BC) and the western technique Zoroaster (S. VII-VI BC); unite West and East (Ortega y Gasset, 2014:138). Buddha and Zoroaster represent that polarity between believing and knowing (Habermas, 2019).

Agnostics understand the "doctrine of the fall": we fell into a world created by an idiotic god or an evil being. G. Pico della Mirandola (1994) wonders who would not want to flee quickly from this world, dominated all of it by an evil being ... and be transported to the celestial Jerusalem? These are the theses defended by John Gray. That idiotic and evil god has been transformed into a secularized idiotic and evil man. Edward O. Wilson considers man to be a tribal carnivore willing to cruelly kill other men, James Lovecraft casts him as a plague on the planet. For Ernst Cassirer (1874-1945) "it is not the material world, but the human, the key to a correct interpretation of the cosmic order" (Lachman, 2013).

The Anthropocene refers us to effervescent anthropological proposals from the beginning of the 20th century in the field of science. We have the "cosmological anthropology" of Max Scheler (1874-1928), the "existential anthropology" of Martin Heidegger (1889-1976), the "biological anthropology" of Helmut Plessner and the "medical anthropology" of Viktor von Weizsäcker (1886- 1957). Ernst Haeckel, a faithful disciple of Charles Darwin, far from suppressing teleology makes it a supreme principle. It is not difficult to see the link between pessimism and misanthropic reflections in John Gray. Sometimes man is the scapegoat for the ecological crisis. At other times he is capitalism (or Capitocene) (Haraway, 2016). We have "the four horsemen of atheism": Richard Dawkins, Daniel Dennet, Christopher Hitchens and Sam Harris.

\subsubsection{Physiology of the Earth}

James Lovelock (2008) in The Guardian, in the face of the new optimism and technological arrogance, invites us to reflect. Geoengineering acts with the planetary climate in the same way that doctors did with diseases before the 40s when we had few drugs on hand: morphine, quinine, aspirin and insulin and little was known about what the mechanism of action of these drugs was. The patients had two ways to deal with the disease: modern physiology: salutogenesis or biomedicine (declaring war on germs: pathogenesis). Are we prepared, if we alter the planetary balance, to take on a permanent onerous task of maintaining the earth's homeostasis? If we use stratospheric aerosols launched from airplanes, as Bill Gates (2021) proposes, even if they are successful, sooner or later we would be faced with the problem of ocean acidity and more. Then we will need other medicines. And so on. Modern physiology would recommend us to rely on the ability of the planet's natural self-regulation, that is, to reinforce salutogenesis and homeostasis. In the health emergency, says Richard Horton (2020), we follow "too narrow approaches" proposes to analyze the interactions between biology, environment, social equalities, etc.

The scientific approach prefers to divide and subdivide a problem, and to attend to interactions, to interdependence, in one word: it ignores the "context". The euro crisis was treated as a highly specialized subject. Political writers, from evening to day, warn of the secondary consequences of this crisis. The euro crisis is "contextualized" as a crisis of the very process of integrating European politics (Habermas, 2011). Monetary experts 
and elites reject these analyses as inaccurate and lacking in "scientific" rigor. Ulrich Beck (2016) pointed out how Draghi's "emergency policy" to save the euro bypassed all the monetary policy rules that the elites had imposed by accelerating the process of European disintegration. The euro crisis could also have been an opportunity of metamorphosing into options for returning to national monetary systems. We are facing a revolution without revolution, a revolution without subject, a revolution instigated by the prevailing circumstances (ck, 1988).

\subsubsection{Metamorphosis and the Manichaean Faustus}

The secondary consequences of the "public bad" that metamorphose into "good" take us back to an "old quarter". It is an almost theological dispute over the meaning of evil. The Faust of J.W. Goethe is Manichaean: it does not mean that "good" and "evil" are mixed. Good has been hidden behind evil. Here arises the antagonistic position between Mani (216-277) and Pelagius (360-420) who was a British monk accusing Augustine of Hippo (354-430) of, under Manichaeism influence, contaminating Christianity with pagan fatalism and "raising evil to the same level as God" (Riechmann, 2017:160).

Environmentalism, unlike the Anthropocene, presents the destruction of the planet as a strictly scientific issue. However, it has theological and metaphysical derivatives. Manuel Castells (2009) identifies environmentalism with a mixture of New Age, neopaganism, counterculturally, etc. There is no shortage of eccentric figures who proclaim: "Earth First!". They consider that we are all animals and human life is, in itself, irrelevant to the cosmos. Environmentalism, over and above the mass of tendencies, leads to an "apocalyptic millennialism" in Martha Lee (1995:140). James Lovelock (2006) sees it inevitable to go to the Eocene and the quagmire in which we find ourselves is not because of stupidity and ignorance but, on the contrary, because of our intelligence and creativity. They accuse the infrastructures of Christianity and humanism, stating that man is the greatest threat to Gaia (Lovelock, 2006).

This is not shared by Vladimir I. Vernadsky, Max Scheler, Edmund Husserl, etc., Colin Wilson (1931-2013) writes "never before in history has humanity had such a depressing view of itself" (Lachman, 2017). Original sin is the excessiveness and arrogance with which man transcends animal consciousness. Jorge Riechmann (2017:159) proposes, instead of "let's celebrate what we are": "let's be afraid of who we are!".

The Anthropocene is also riddled with anthropological, theological, philosophical, sociological questions. Every species has its own habitat, on the other hand, man lacks a natural habitat of his own: Earth for man is uninhabitable (ungewohnbar). That's why you need to manufacture (bauen) its habitat (wohnen). The man, for Ortega y Gasset (2014:209-210), "is not an animal... it is an intruder in the so-called nature. It comes from outside of it, incompatible with it, essentially misfit." Man, then, has to create an "inside", an "inner world", a "super naturalness", where he can take refuge from the weather. The animal lacks, says Max Scheler, that "chez soi". That "within itself" (Ortega y Gasset, 2019: 51). That is why man has that "eccentric" position, which Helmuth Plessner (1981) points out: We are Lieb (life) and Körper (body). We are part of the earth (red) and the cosmos sky (blue). Man, for José Ortega y Gasset (2014:209) "is on Earth, but does not inhabit -wohnt- in it"; for, unlike other beings (mineral, vegetable and animal) "the earth is for man uninhabitable-unbewohnbar" (Ortega y Gasset, 2014:209). Jorge Riechmann (2017) proposes us to live as good orphans, that is, to accept finitude and contingency.

The West must learn from the East to look inward, to develop meditation. Buddha who looks inward and Zoroaster who looks at the cosmos, are two currents that unite 
and rejuvenate in Christianity (Habermas, 2019:361). Manichaeism seeks to inset evil gently. This does not mean that we have to resist evil. Evil becomes, as we saw in Ulrich Beck (2014), an agent of "emancipatory catastrophism". "Public goods" are not "effects of goods but the positive side effects of bad". It is not easy to understand. We can observe it under three lenses: (I) the anticipation of a global catastrophe that violates the sacred (unwritten) norms of human existence and civilization; (ii) an anthropological shock and, (iii) a social catharsis.

\section{What's after the Anthropocene?}

"Sustainable development" is gaining detractors. James Lovelock (2006) believes that we must abandon "sustainable development" in favor of "sustainable withdrawal". The thesis of James Lovelock, John Gray and others is that the time for "sustainable development" is over. The original sin lays in not accepting our guilt, finitude, contingency, etc. We are not in the context of a scientific discussion on climate change, but of anthropological and philosophycal approaches. The earth is sick of humanity: a plague is not an argument, it is an assertion of pathological pessimism.

In the same vein as James Lovelock (2006) Edward O. Wilson (2016) sees man as a tribal carnivore willing to kill on behalf of his tribe. Never before has humanity had such depressing visions of itself. It is not a question of humanity following frivolous currents of thought that deny science. What is affirmed is the great failure of what we consider the most valuable: our capacity to learn (Álvarez-Pereira, 2019).

We must support an orderly, planned, controlled 'sustainable withdrawal', because for 'sustainable development' there is no time. From the Anthropocene, we will not go to Holocene but to the Eocene: a planet with a temperature increase of 7 degrees (Lovelock, 2008).

\subsection{Progress and the dark side of history}

The Anthropocene refers to more than just altering the social relations of production. Technological acceleration is altering the moral foundations of modernity and our own self-understanding as a species. Jürgen Habermas points out that science and technology become technocratic consciousness, on the one hand, and, on the other hand (a century after the words of Karl Marx) science assumes the role of bourgeois ideology destroyed by the innovative dynamics themselves (Habermas, 1968).

Here we find the equivocal concept of rationality as pointed out, a century ago in the "Dialectic der Aufklarung" Theodor W. Adorno (1903-1969) and Max Horkheimer (1895-1973) (1997). We should add the radicalized criticism of Herbert Marcuse (18981979). Scientific and technical progress involves not only the destruction of social relations and institutional frameworks, but also the destruction of the planet and the human substance (Marcuse, 1954).

The fusion of the biotechnology, bioengineering and infotechnology revolution will allow us to move from manipulating the "outer world" to manipulating the "inner world". Man, from the seventeenth century, conquered an enormous power to manipulate the "outside world". The result of that is the current "ecological collapse" due to not having understood the complexity of global ecology (López Ortega, et. al., 2021:166). In the 21th century we are gaining the power to manipulate the inner world without having the 
slightest idea of how it works. It opens up terrifying narratives and the coming of the moment of "singularity" like mentioned by Ray Kurzweil (Weizsäcker, Wijkman, 2019).

\subsection{The role of the observer}

Man occupies an eccentric place. He becomes a geological force and, at the same time, is expelled from the cosmos, from knowledge and from history. The image of the modern "world of science" was purged from the subjective images of the "world of life" (Habermas, 2012). There is a paradoxical situation between the social sciences and the human sciences; Carl Gustav Jung (1875-1961) (2019:205) criticizes that the humanities prefer to avoid the audacious attempt to enter the unknown, the invisible, while physics, to enable a certain problem to be more or less fruitful, unfolds in an apparent "contradictio in adiecto" (contradiction in terms).

Galileo (1564-1642) was aware that modern science is not a compendium of knowledge of the world when he asserts "mente concipio", that is, "I conceive it in my mind" (Gadamer, 1993). The theory of relativity dethrones Euclidean geometry. Galileo and Newton made the universe Euclidean because reason dictated it (Ortega y Gasset, 1938:153). There is a rational anthropocentrism: forcing nature to behave rationally and adopting the rational point of view: "sub specie aeternitatis" (in a universal perspective) (Ortega y Gasset, 1938:148). Albert Einstein (1879-1955) understands that the distance of two objects belongs to the objects themselves: there is no space apart from physical objects There is no matter without form and observation without an observer. Time becomes a fourth dimension.

It is not a thesis to be established, it is a model conceived by the observer. The meaning of a model is not to say "this is so" but to determine a point of vue. (Jung, 2011:535-536). "In the cosmic spectacle" says José Ortega y Gasset (1939:149) "there is no spectator without locality". In the Anthropocene, pure reason cannot walk without going hand in hand with experience.

Manuel Arias-Maldonado $(2015: 18,24,42)$ reminds us that natural history is also social history. Science and ecology have renounced historical consciousness and, therefore, also utopia. We are surrounded by dystopias and apocalyptic hypotheses based on reckless speculation. In opposition, we have the thesis of the end of science; or, at least, as Jeremy Baski (2015) points out, what until now we understood by thinking in scientific terms: dualistic, binary and, therefore, exclusive. We go back to the romantic thought of J.G. Herder (1744-1802) and J.W. Goethe (1749-1832) passing through Alexander Humboldt (1769-1859).

The bodhisattva has a negative assessment of life. In Christianity, what is wanted, is to return to the spiritual world from which it has fallen, Christianity does not disdain the earthly. For the Buddhist there is no way of salvation only of flight, for the Christian there is the way of bliss: the immanent lacks value, only the capacity for transmutation expressed at the Last Supper has value. Life is a training for death (Ortega y Gasset, 1938:64). Here, man, says José Ortega y Gasset (2014:85) is "at a natural and supernatural time, a kind of ontological centaur"; body and soul are things, whereas man is neither one nor the other, but "a drama, and a struggle to become what it has to be" (2014:87). The scientific revolution, with a nature that rests on the absence of human footprints, is challenged (Arias Maldonado: 2014).

\section{Conclusions}


The Anthropocene comes to provoke a renewal of conceptual frameworks. In this paper we have presented an outline of the enormous task involved in the elaboration of a new cartography. It opens us to a debate that reminds us of old complaints from the romantic thinkers of a century ago. Richard Hurton (2018). Maren Meinhardt (2019), in her captivating new biography of Alexander von Humboldt, discovers a scientist who annealed measurement with mind. The result transformed European thought in ways that resonate powerfully today.

Those authors inspired by J.W. Goethe have generated interesting intellectual constructions that can become sources in our work with the Anthropocene proposal. This integration of observer and observed is not intellectual speculation. "What we observe", points out Werner Heisenberg (1901-1976), "is not nature itself, but nature exposed to our method of questioning" (Heisenberg, 1979; Capra, 1996).

Alexander von Humboldt understands science as a longing for the Wide and Unknown (Hurton, 2018). For Werner Heisenberg (1979) from I. Newton, science has sacrificed the "living and immediate understanding of nature." In this idea that is present the criticism that J.W. Goethe makes I. Newton. Goethe can now get a renewed understanding. The Anthropocene poses a new epistemology. This places us in an argument far from the one that insists on the natural limits of growth, to find a new emancipatory scheme (Arias-Maldonado, 2021). Philosophy needs to be ashamed of the imagination not based on reason. It is a thesis exposed in the "das älteste Systemprogramm" (1796/1797). It returns us to that union between the oriental technique (internal) and the western technique (external): Buddha and Zoroaster United.

Environmentalism unites diverse currents in opposition to Anthropocentrism; it takes us back to old quarrels about the meaning of evil. The human being begins to consider that evil is an integral part of his essence. Man's task would be to transform evil into good (Beck, 2016). In front of us we have currents that push us to return to a cosmic childhood, that wish to oppose the evolution of human beings (Piulats, 2018: 377).

The paradox is the lack of utopia in environmentalism. The anti-utopianism of ecologists reflects the lack of historical consciousness and the contingency of mental infrastructures (Welzer, 2013). They rule out the alternative to the apocalypse. It is an eschatological millenarian thought that awaits the "final judgment" to solve the problem of "original sin". The purpose of the paper is not to provide evidence of man's geological impact on the earth, but to show the metamorphosis of our conscience and vision of the world and the contingency of our mental infrastructures.

Climatologists have had the leading voice in the climate crisis, while anthropologists, sociologists, and philosophers have had a marginal voice. Environmentalists have found a horror story in describing climate change and the Anthropocene. Jorge Riechmann (2017.261) speaks of "cosmic pessimism". The question is whether there is a bridge between "the facts" and the claim that "we live in hell". Donna J. Haraway (2016) builds a story in which the ingredients are: biology, ecology, feminism and science fiction (horror). Manuel Arias-Maldonado (2015: 44) points out the unifying element of environmentalism: the rejection of anthropocentrism. Not all environmentalism thrives on the Norwegian philosopher Arne Neas (1912-2009). We use controversial assumptions; like the Gaia hypothesis: it is not reasonable to use against this hypothesis the same arguments that are used to deny the existence of God by atheists. 
Geology studies the epidermis of the earth: the earth's crust. But atmospheric chemists cannot exclude life from this study. We live in an anthropomorphic land. The reasoning that is the earth that needs to adapt itself in order to create and support life has to be taken with caution. Likewise, we should take with caution that there are no longer established borders between the organic and the inorganic world, there is a symbiogenesis between the two worlds. It is difficult to think of a planet without the existence of superior mammals and without man. In the Anthropocene, we are invited to reverse the decoupling between geology and anthropology.

\section{References}

Aanen, D.R.; Eggleton, P. 2017. Symbiogenesis: Beyond the endosymbiosis theory? Journal of Theoretical Biology, 434 (7): 99-103. [Crossref]

Álvarez Pereira, C. 2019. Reflexionar sobre cómo reflexionamos. In Come on! Capitalismo, cortoplacismo, población y destrucción del planeta. Weizsäcker, E.U. von; Wijkman, A. Barcelona: Deusto, pp. 206-210.

Arendt, H. 1958. The Human Condition. Chicago: University of Chicago Press. [Google Scholar]

Arias-Maldonado, M. 2014. Antropoceno: el fin de la naturaleza. Revista de Libros. https://www.revistadelibros.com/antropoceno-el-fin-de-la-naturaleza/

Arias-Maldonado, M. 2015. Environment and Society. Socionatural Relations in the Anthropocene. New York, Dordrecht, London: Springer. [Google Scholar]

Arias-Maldonado, M. 2016. El giro antropocénico. Sociedad y medio ambiente en la era global. Política y Sociedad, 53 (3): 795-814. [Crossref]

Arias-Maldonado, M. 2017. Antropoceno sin Antropoceno. Eunomía. Revista en Cultura de la Legalidad. 13.:321-326. [Crossref]

Arias-Maldonado, M. 2018. Science or Fiction? What the Anthropocene Means for EPT. Science and Environmental Political Theory. WPSA, Sant Francisco. https://core.ac.uk/download/pdf/214832968.pdf

Arias-Maldonado, M. 2018a. Antropoceno: La política en la era humana. Barcelona: Taurus/Penguin Random Huse. [Google $\underline{\text { Scholar] }}$

Arias-Maldonado, M. 2021. Reformulating emancipation in the Anthropocene: From didactic apocalypse to planetary subjectivities. European Journal of Social Theory. 84. [Crossref] [Google Scholar]

Baskin, J. 2015. Paradigm dressed as epoch. Environmental Values, 24, 1:9-29. [Crossref]

Beck, U. 1988. Gegengifte: Die organisierte Unverantwortlichkeit. Frankfurt a M.: Suhrkamp. [Google Scholar]

Beck, U. 2014. Emancipatory catastrophism: What does it mean to climate change and risk society? Current Sociology, 63, Issue 1:75-88. [Crossref]

Beck, U. 2016. The Metamorphosis of the World. How Climate Change is Transforming Our Concept of the World. Cambridge: Polity Press. [Google Scholar]

Benjamin, W. 1980. Über den Begriff der Geschichte. In. Gesammelte Schrifte, I-2: Frankfurt a M.: Suhrkamp. pp. 691-704. First published 1940.

Berg, R. Vogel, M. 1930. Die Grundlagen einer richtigen Ernährung. Dresde: Deutscher Verlag für volkswohlfahrt. [Google Scholar]

Bertrand, G.H.V. 2014. Vernadsky's philosophical legacy: A perspective from the Anthropocene. The Anthropocene Review. 1 (2):126-136. [Grossref]

Broecker, W. S. 2002. How to Build a Habitable Planet. Arizona: Eldigio Press. First published 1985.

Broecker, W., Barker, S. 2007. A 190\%o drop in atmosphere's $\Delta 14$ C during the "Mystery Interval” (17.5 to $14.5 \mathrm{kyr})$. Earth and Planetary Science Letters, 256(1):90-99. [Crossref] 
Castells, M. 2009. The Information Age. Economy, Society and Culture: A Summary: II. The Power of Identity. Blackwell, Oxford, Malden, MA. [Crossref]

Capra, F. 1996. The Web of Life. A new synthesis of mind and matter. New York: Anchor Book. [Google Scholar]

Ceroni Galloso, M. 2012. Perú, el país de las oportunidades perdidas en ciencia: el caso de los fertilizantes. Rev. Soc.

Quim. 78. http://www.scielo.org.pe/scielo.php?script=sci_arttext\&pid=S1810-634X2012000200009

Crutzen, P. J.; Stoermer, E.F. 2000. The 'Anthropocene'. Global Change Newsletter, 41:17-18.

Crutzen, P. 2002. Nature: Geology of mankind. Nature, 415: 23 [Crossref]

Duarte, C.; Pardo, M.; et. al. 2006. Cambio Global. Impacto de la Actividad Humana sobre el Sistema Tierra. Madrid: CSIC. https://e-archivo.uc3m.es/handle/10016/8520

EU Agricultural. 2019. Fertilizers in the EU. Prices, trade and use. Agricultural Markets Briefs, 15. https://ec.europa.eu/info/sites/default/files/food-farming-fisheries/farming/documents/market-brief-

fertilisers_june2019_en.pdf

Fechner, G.T. 2011. Einige Ideen zur Schöpfungs- und Entwicklungsgeschichte der Organisme. Hamburg: Tredition Clasics. First published 1873. [Google Scholar]

Foster, J.B.; Clark, B. 2018. The Robbery of Nature. Capitalism and the Metabolic Rift. Monthly Review. 70 (3): 1-20. [Crossref]

Foster, J.B. 2000. Marx's Ecology. Materialism and nature. New York: Monthly Review Press. [Google Scholar]

Furukawa, Y., et a (2019) Extraterrestrial ribose and other sugars in primitive meteorites. PNAS, 111 (49): $24.440-24.445$.

[Crossref]

Gadamer, H-G. 1993. Über die Verborgenheit der Gesundheit. Aufsätze und Verträge. Frankfurt a M. Suhrkamp.

Garrood, W., et al. 2021. Analysis of off-target effects in CRISPR-based gene drives in the human malaria mosquito. PNAS. [Crossref]

Gates, B. 2021. How to Avoid a Climate Disaster: The Solutions We Have and the Breakthroughs We Need. New York. Alfred A. Knopf.

Goethe, J.W. 1982. Schriften zur Naturwissenschaft. Stuttgart: Reclam. First published 1793.

Good, A. 2018. Toward nitrogen-fixing plants. Science, 359 (6378): 869-870. [Crossref]

Gray, J. 2003. Straw Dogs: Thoughts on Humans and Other Animals. London: Grata Books. [Google Scholar]

Gray, J. 2015. The Soul of the Marionette: A Short Inquiry into Human Freedom. New York: Farrar, Strau and Giroux. [Google Scholar]

Habermas, J. 1963. Theorie und Praxis. Sozialphilosophische Studien. Frankfurt a M. Suhrkamp. [Google Scholar]

Habermas, J. 1968. Technik und Wissenschaft als “Ideologie"? Klassenkampf und Ideologie heute. Merkur, 243: 591610/244: 682-693. [Crossref] [Google Scholar]

Habermas, J. 2001. Die Zukunft der menschlichen Natur. Aufdem Weg zu einer liberalen Eugenik? Frankfurt a M.: Suhrkamp. [Google Scholar]

Habermas, J. 2006. Political Communication in Media Society: Does Democracy Still Enjoy an Epistemic Dimension? The Impact of Normative Theory on Empirical Research. Communication Theory, 16 (4): 411-426. [Crossref]

Habermas, J. 2011. An Gründen für eine Gemeinschaft fehlt es nicht, wohl aber an einer politischen Willen -und an Verantwortg. Sueddeutsche Zeitung, 7.4.2011. https://www.sueddeutsche.de/politik/europapolitik-merkels-vondemoskopie-geleiteter-opportunismus-1.1082536-7

Habermas, J. 2012. Nachmetaphysisches Denken II. Aufsätze und Repliken. Frankfurt a M.: Suhrkamp. [Google Scholar] Habermas, J. 2013. Im Sog der Technokratie. Kleine Schriften XII. Frankfurt a M.: Suhrkamp. [Google Scholar]

Habermas, J. 2019. Auch eine Geschichte der Philosophie - Band 1: Die okzidentale Konstellation von Glauben und Wissen. Band 2: Vernünftige Freiheit. Spuren des Diskurses. Frankfurt a M.: Suhrkamp. [Google Scholar]

Hamilton, C. 2016. The Anthropocene as rupture. The Anthropocene Review, 2 (1): 59-72. [Crossref] 
Harari, Y.N. 2018. 21 Lessons for the 21st Century. London: Jonathan Cape. [Google Scholar]

Harawey, D. 2016. Staying with the trouble: making kin in the Chthulucene. Duke: Duke University Press. [Crossref]

Haraway, D. 2015. Anthropocene, Capitalocene, Plantationocene, Chthulucene: Making Kin. Environmental Humanities, 6: 159-165. [당s $]$

Heidegger, M. 1961. Nietzsche II. 1939-1941. Stuttgart: Neske.

Heidegger, M. 1997. Der Satz vom Grund. Pfullingen: Neske. First published 1957. [Google Scholar]

Heine, H. 1969-1976. Sämtlichen Schriften. Munich: Hanser.

Heisenberg, W. 1979. Philosophical problems of quantum physics. Woodbridge, CT: Ox Bow Press. [Google Scholar]

Horkheimer, M. 1997. Gesammelte Schriften, Band 5. 1940-1960. Frankfurt a M.: Fischer.

Horton, R. 2018. Offline: Welcome to the new Age of Romanticism. The Lancet, 391(10120): 522. [Crossref]

Horton, R. 2020. COVID-19 is not a pandemic. The Lancet, 396 (10255):874. [Crossref]

Husserls, E. 1935. Die Krisis des europäischen Menschentums und die Philosophie. Wien: Online Texts, 7/10 Mai 1935. http://www.hs-augsburg.de/ harsch/germanica/Chronologie/20Jh/Husserl/hus_kris.html

IAASTD. 2009. Agricultures at a Crossroads. Washington: Island Press. http://www.agassessmentwatch.org/report/Global\%20Report\%20(English).pdf

IPCC. 2019. Climate Change and Land. An IPCC Special Report on climate change, desertification, and degradation, sustainable land management, food security, and greenhouse gas fluxes in terrestrial ecosystems. https://www.ipcc.ch/site/assets/uploads/2019/11/SRCCL-Full-Report-Compiled-191128.pdf

Jones, N. 2011. The human epoch. Nature, 473, 133. [Crossref]

Jung, C. G. 2011. Von den Wurzeln des Bewusstseins. Studien über den Archetypus. Zürick: Racher-Verlag. First published 1954.

Kemp, L. 2021. 'Stomp Reflex': When governments abuse emergency powers. BBC, 28.4 .2021$. https://www.bbc.com/future/article/20210427-the-stomp-reflex-when-governments-abuse-emergency-powers

Kirchfeld, F.; Boyle, W. (1994) Nature doctors: pioneers in naturopathic medicine. Medicina Biologica. Portland/ Oregon/ Ohio: Buckeye Naturopathic Press. [Google Scholar]

Lachman, G. 2013. The Caretakers of the Cosmos: Living Responsibly in an Unfinished World. Edinburg: Floris Book. [Google Scholar]

Lachman, G. 2017. Lost Knowledge of the Imagination. Edinburg: Floris Books. [Google Scholar]

Lee, M. 1995. Earth First! Environmental Apocalypse. New York: Syracuse University Press. [Google Scholar]

Lehman, R.M.; et al. 2015. Understanding and Enhancing Soil Biological Health: The Solution for Reversing Soil Degradation. Sustainability. 7 (1): 988-1027. [Crossref]

Lenton, T.M.; et. al. 2020. Life on Earth is hard to spot. The Anthropocene Review, 7 (3):248-272. [Crossref]

López Ortega, J.; et. al. 2021. Economía circular: Nuevas formas de pensar y actuar en un territorio socialmente sostenible y responsable (TS2R). In Economía circular: fundamentos y aplicaciones. Fernandez Izquierdo, M.E.; Lopez Martínez, G. Pamplona: Aranzadi/Civitas-Thomas Routers, pp. 159-178.

Lovelock, J. 2006. The revenge of Gaia: Earth's Climate Crisis and the Fate of Humanity. New York: Basic Book. [Crossref] Lovelock, J. 2008a. A geophysiologist's thoughts on geoengineering. Philos Trans A Math Phys Eng Sci. 13; 366(1882): 3883-90. [Crossref]. PMID: 18757274.

Lovelock, J. 2008b. Medicine for a feverish planet: kill or cure? The Guardian, 1.9.2008. https://www.theguardian.com/environment/2008/sep/01/climatechange.scienceofclimatechange

Lovelock, J.; Kump, L.R. 1994. Failure of climate regulation in a geophysiological model. Nature, 369: 732-734. [Crossref Lovelock, J.; Margulis, L. 1974a. Biological modulation of the Earth's atmosphere. Icarus, 21(4): 471-489. [Crossref] Lovelock, J.; Margulis, L. 1974b. Atmospheric homeostasis by and for the biosphere: the gaia hypothesis. Tellus, 26 (12):2-10. [Crossref] 
Lutz-Bachmann, M.; Fidora, A. (Hgg.) 2008. Handlung und Wissenschaft. Die Epistemologie der praktischen Wissenschaften im 13. und 14. Jahrhundert. Action and Science. The Epistemology of the Practical Sciences in the 13th and 14th Centuries. Berlin: Akademie Verlag.

Mancuso, S. 2019. La nazione delle piante. Roma: Laterza. [Google Scholar]

Marcuse, H. 1954. One-dimensional man. Boston: Bacon Press. [Google Scholar]

Margulis, L. 1974. Five-Kingdom Classification and the Origin and Evolution of Cells. In Evolutionary Biology. Dobzhansky T., Hecht M.K., Steere W.C. (eds). Boston, MA: Springer. [ㄷossref]

Margulis, L.; Sagan, D. 1986. Microcosmos. Four Billion Years of Evolution from Our Microbial Ancestors. Berkeley/ Los Angeles/ London: University of California Press. [Google Scholar]

Marx, K. 1985. Das Kapital. Kritik der politische Ökonomie, III. Berlin: Dietz Verlag. First published 1894.

Meinhardt. M. 2019. Alexander Von Humboldt: How the most famous scientist of the romantic age found the soul of nature. New York: BlueBridge. [Google Scholar]

Müller, D. M. 2020. Chemistry of the Climate System. Berlin: Walter de Gruyter GmbH \& Co KG. [Crossref]

Mulvaney, R.L.; Khan, S.A.; Ellsworth, T.R. 2009. Synthetic nitrogen fertilizers deplete soil nitrogen: a global dilemma for sustainable cereal production, J. Environ Qual, 38:2295-2314. [Crossref]

Mumford, L. 1971. The Myth of the Machine: Technics and human Development. New York: I. HBJ Book. First published 1967. [Google Scholar]

Naredo, J.M.; Valero, M. 1999. Desarrollo económico y deterioro ecológico. Madrid: Visor. [Google Scholar] OCDE/FAO. 2020. OCDE-FAO Agricultural Outlook 2020-2029. Paris: Rome/OCDE Publishing. [ㄷossref]

Ortega y Gasset 2019. Ideas y creencias y otros ensayos. Alianza editorial, Madrid. First published 1940.

Ortega y Gasset J. 1938. Temas de nuestro tiempo. Madrid: Espasa Calpe, Madrid.

Ortega y Gasset, J. 2014. Ensimismamiento y alteración. Meditación de la técnica y otros ensayos. Madrid: Alianza Editorial. First published 1939. [Google Scholar]

Palsson, G. et al. 2013. Reconceptualizing the 'Anthropos' in the Anthropocene: Integrating the social sciences and humanities in global environmental change research. Environmental Science E Policy. 28: 3-13. [Crossref]

Paracelsus, T. 1965. Medizinische Schriften. 1520-1570 (Will-Erich Peuckert) Werke I. Darmstadt: Wissenschaft Buchges.

Peinado Lorca, M. 2019. Polvo de estrellas: de cómo la vida pudo caer del cielo. The Conversation, 4.12.2019. https://theconversation.com/polvo-de-estrellas-de-como-la-vida-pudo-caer-del-cielo-128153

Pico della Mirandola, G. 1994. Oratio de hominis dignitates. Pordenone: Edizioni Studio Tesi. [Google Scholar]

Piulats, O. 2017. La ciencia espiritual de la naturaleza. Barcelona: Carena.

Piulats, O. 2018. Descubre la oculta naturaleza del mar. Barcelona: Carena.

Plessner, H. 1981. Die Stufen des Organischen. Gesammelte Schriften IV. Frankfurt a M. Suhrkamp.

Prigogine, I.; Stengers, I. 1984. Order out of Chaos: Man's New Dialogue with Nature. Nuew York: Bantam Books.

[Google Scholar]

Riechmann, J. 2017. ¿Vivir como Buenos huérfanos? Ensayos sobre el sentido de la vida en el siglo de la Gran Prueba. Madrid: Catarata. [Google Scholar]

Rockström, J.; et al. 2009. A safe operating space for humanity. Nature, 461: 472-475. [Crossref]

Steffen, W.; Crutzen, P.; McNeill, J. R. 2007. The Anthropocene: Are Humans Now Overwhelming the Great Forces of Nature? Ambio, 36 (8): 614-621. [Crossref]

Steiner, R. (1987). Einleitungen zu Goethes Naturwissenschaftlichen Schriften. GA 1. Dornach: RSV. First published 18841897. [Google Scholar]

Steiner, R. 1990. Goethes Weltanschauung. GA 6. Dornach: RSV. First published 1897. [Google Scholar]

Steiner, R. 1981. Geisteswissenschaftliche Erläuterungen zu Goethes «Faust»: Faust, der strebende Mensch. GA 273. Dornach:

RSV. First published 1916-1924. [Google Scholar] 
Steiner, R. 2010. Geisteswissenschaftliche Grundlagen zum Gedeihen der Landwirtschaft. GA 327. Dornach: RSV. First published 1924. [Google Scholar]

Stoermer, E.F. 1984. Research on Great Lakes Algal Communities: Problems from the Past, Lessons for the Future. Journal of Great Lakes Research, 10 (2): 143-155. [Crosseref]

Suess, E. 1875. Die Entstehung der Alpen. Wein: Wilhelm Braummuller. [Google Scholar]

Tomassello, M. 2002. Die kulturelle Entwicklung des menschlichen Denkens: Zur Evolution der Kognition. Suhrkamp. Franfurt a M. [Google Scholar]

Valero, A. 2019. Materiales: Más allá del cambio climático. In Come on! Capitalismo, cortoplacismo, población y destrucción del planeta. Weizsäcker, E.U.; Wijkman, A. Barcelona: Deusto, pp. 206-210.

Vernadsky, V.I. 1998. The Biosphere. New York: Copernicus. First published 1926. [Google Scholar]

Weizsäcker, E.U. von: Wijkman, A. 2018. Come on! Capitalism, Short-termism, Population and the Destruction of the Planet. New York: Springer.

Welzer, H. 2008. Klimakriege. Wofür im 21. Jahrhundert getötet wird. Frankfurt a M.: S. Fischer.

Welzer, H. 2013. Selbst denken: eine Anleitung zum Widerstand. Frankfurt a M.: S. Fischer Verlag. [Google Scholar] Wilson, E. O. 2016. Half-Earth: Our Planet's Fight for Life. New York: Liveright. [Google Scholar] 